\title{
Williamsia muralis gen. nov., sp. nov., isolated from the indoor environment of a children's day care centre
}

\author{
Peter Kämpfer, ${ }^{1}$ Maria A. Andersson, ${ }^{2}$ Fred A. Rainey, ${ }^{3}$ \\ Reiner M. Kroppenstedt ${ }^{4}$ and Mirja Salkinoja-Salonen ${ }^{2}$
}

\author{
Author for correspondence: Peter Kämpfer. Tel: +4964199 37352. Fax: +496419937359. \\ e-mail: peter.kaempfer@agrar.uni-giessen.de
}

\footnotetext{
1 Institut für Angewandte Mikrobiologie, JustusLiebig Universität, Senckenbergstr. 3, D-35390 Giessen, Germany

2 Department of Applied Chemistry and Microbiology, PO Box 56 (Biocentre), 00014 University of Helsinki, Finland

3 Department of Biological Sciences, 508 Life Sciences Building, Louisiana State University, Baton Rouge, LA 70803, USA

${ }^{4}$ DSMZ-Deutsche Sammlung von Mikroorganismen und Zellkulturen $\mathrm{GmbH}$, Mascheroder Weg $1 \mathrm{~b}$, D-38124 Braunschweig, Germany
}

\begin{abstract}
The taxonomic status of an actinomycete (MA140/96') isolated from indoor building materials of a children's day care centre was studied using the polyphasic approach. The cell morphology was atypical for an actinomycete, electron microscopy revealed a hairy surface, highly unusual for Gram-positive bacteria. The organisms grew at 10-37 ${ }^{\circ} \mathrm{C}$, no growth was visible at $5{ }^{\circ} \mathrm{C}$ and $45{ }^{\circ} \mathrm{C}$ in $5 \mathrm{~d}$. The cell wall contained the diamino acid meso-diaminopimelic acid and the sugars arabinose, galactose, mannose and ribose. The phospholipids phosphatidylethanolamine, phosphatidylinositol, phosphatidylglycerol and diphosphatidylglycerol were detected. The only menaquinone found was MK$9\left(\mathrm{H}_{2}\right)$. The fatty acid pattern was composed of palmitic acid $(23.6 \%)$ palmitoleic acid $(16.5 \%)$ and another hexadecenoic acid 16:1cis11 (1.4\%), oleic acid $(29.9 \%)$, stearic acid (2.9\%) and the 10-methyl-branched tuberculostearic acid (23.2\%). A gas-chromatographic analysis of the mycolic acid revealed a carbonchain length of $C_{50}-C_{56}$. The $G+C$ was $64.8 \mathrm{~mol} \%$. The results of 165 rDNA sequence comparisons revealed that strain MA140/96 represents a new lineage in the suborder Corynebacterineae of the order Actinomycetales. Therefore, it was concluded that strain MA140/96' should be assigned to a new genus and species, for which the name Williamsia muralis gen. nov., sp. nov. is proposed. The type strain of the species is MA140/96' (= DSM 44343').
\end{abstract}

Keywords: Williamsia muralis gen. nov., sp. nov., actinomycete, indoor contaminant

\section{INTRODUCTION}

The colonization of indoor building materials with bacteria and fungi is a common problem in case of high moisture (Maroni et al., 1995). In an extensive study of the bacteria, moulds and their toxins found in waterdamaged buildings, Mycobacterium species and Gordonia species were detected (Andersson et al., 1997). Rapidly growing mycobacteria, especially, seem to be the major bacterial colonizers of water-damaged sites; however, it can be expected that several other actinomycetes are present, which remain to be described.

In a survey of a children's day care centre, no mycobacteria or gordoniae were found in non-damaged areas; instead, a different type of actinomycete was

The EMBL accession number for the 165 rDNA sequence of strain MA140/96 ${ }^{\top}$ is $Y 17384$. detected. One isolate from these samples was subjected to an extensive polyphasic characterization. In this paper we describe the morphological, physiological, chemotaxonomic and phylogenetic characteristics of this organism. On the basis of our results and the unique taxonomic properties of the organism, it can be concluded that strain MA140/96 $6^{\mathrm{T}}$ represents a new genus and a new species, for which we propose the name Williamsia muralis gen. nov., sp. nov.

\section{METHODS}

Isolation. The organism (strain MA140/96 ${ }^{\mathrm{T}}$ ) was isolated from non-water-damaged building material of a children's day care centre as described elsewhere (Andersson et al., 1997). The strain was isolated from gypsum liner walls of a children's sleeping room at $22{ }^{\circ} \mathrm{C}$ on tryptone soy agar plates (Difco) incubated for $14 \mathrm{~d}$.

Morphological characteristics. Cell morphology was examined by phase-contrast microscopy with a light microscope (Leitz). Motility was studied by the hanging drop 
method. Cell dimensions were measured with an ocular $(\times 10)$ and an objective $(\times 100 / 1 \cdot 25)$. Gram staining was performed by using Hucker's modification (Gerhardt et al., 1994). Colony morphology was studied by using a stereo microscope (Olympus model SZ 11). For electron microscopy the cells were grown on tryptone soy agar for $7 \mathrm{~d}$ at $28^{\circ} \mathrm{C}$. Thin sections were prepared as described previously (Andersson et al., 1995) and negative stainings as described by Nohynek et al. (1995).

Physiological characteristics. The effects of different temperatures on growth were determined on Bacto nutrient agar incubated at $5,10,28,37,45$ and $50^{\circ} \mathrm{C}$. Physiological tests in microtitre plates were done as described previously (Kämpfer et al., 1997). Tests were read after $7 \mathrm{~d}$ at $30^{\circ} \mathrm{C}$.

Chemotaxonomy. Strain MA140/96 ${ }^{\mathrm{T}}$ was grown on solidified glucose/yeast extract/malt extract DSMZ (Deutsche Sammlung von Mikroorganismen und Zellkulturen) medium no. 65 (DSMZ Catalogue of Strains, 1998 ) at $28^{\circ} \mathrm{C}$ for $3-5 \mathrm{~d}$. Cell material for analyses of fatty acids and mycolic acids were scraped from trypticase soy broth agar plates (DSMZ medium no. 535). For all other chemotaxonomic analyses the strains were grown in trypticase soy broth collected by centrifugation washed twice with distilled water and freeze-dried.

Analysis of cell-wall amino acids and sugars. The amino acid and sugar analysis of whole-cell hydrolysate followed described procedures (Staneck \& Roberts, 1974).

Determination of acyl-type of cell wall. The acyl-type of cell wall was determined using a modification of the colorimetric the method of Uchida \& Aida (1977). In contrast to the original procedures, the whole-cell hydrolysate was neutralized by passing it through an ion-exchange column (Analytichem Bond Elut SCX; Varian).

Extraction and analysis of isoprenoid quinones and polar lipids. Isoprenoid quinones were extracted and purified using the small-scale integrated procedure of Minnikin et al. (1984). Dried preparations were dissolved in $200 \mu \mathrm{l} \mathrm{2-}$ propanol and $1-10 \mu 1$ amounts separated by HPLC without further purification. The menaquinones were separated by HPLC on Lichrosorb RP-18 at $40^{\circ} \mathrm{C}$ using acetonitrile/2propanol $(65: 35, \mathrm{v} / \mathrm{v})$ as solvent (Kroppenstedt, 1985; Kroppenstedt et al., 1981). Polar lipids were extracted, examined by two-dimensional TLC and identified using published procedures (Minnikin et al., 1984).

Preparation and analysis of fatty and mycolic acids. The fatty acid methyl esters (FAMEs) and mycolic acid methyl esters (MAMEs) were prepared from 40-80 mg wet cells (Miller \& Berger, 1984). The extracts of the methanolysates were split. One half $(0.3 \mathrm{ml})$ of the extracts were used for the gaschromatographic analysis of the FAMEs, and the other half was used for analysis of the MAMEs. For the analyses of the MAMEs by high-temperature gas chromatography, the hydroxy group of the MAMEs had to be converted to their trimethylsilylethers by a silylation reagent. The trimethylsilylated derivatives of the mycolic acids were prepared by mixing the extract with $0.1 \mathrm{ml}$ of a solution containing $\mathrm{n}$ methyl-n-(trimethylsilyl)-heptafluorobutyramide and trimethylchlorosilane (10:1, v/v; Macherey \& Nagel, Düren, Germany).

The mixtures of FAMEs and silylated derivatives of the MAMEs were analysed by capillary gas chromatography, using a Hewlett Packard model 5898A gas chromatograph run with Microbial Identification Software (MIDI). For FAME analysis, standard Microbial Identification System
(MIS) conditions were used (Sasser, 1990). The trimethylsilylated derivatives of the MAMEs were analysed by hightemperature gas chromatography with a model HP 5790A gas chromatograph (Hewlett Packard) equipped with a flame-ionization detector and a $12 \mathrm{~m}$ type HT5 column (part no. 051385; SGE, Victoria, Australia), using $\mathrm{H}_{2}$ as carrier gas at a flow rate of $30 \mathrm{ml} \mathrm{min}{ }^{-1}$. The oven temperature was increased from 210 to $400^{\circ} \mathrm{C}$ at a rate of $10^{\circ} \mathrm{C} \mathrm{min}-1$. The final temperature was kept for $7 \mathrm{~min}$. Peaks of the derivatives were identified by comparing their retention times with those of known standard mycolic acids (Klatte, 1994). In addition the mycolic acids were analysed by TLC following the procedure of Minnikin et al. (1975).

Base composition of DNA. The base composition of DNA and the calculation of the $\mathrm{G}+\mathrm{C}$ content was determined as described elsewhere (Nohynek et al., 1995).

165 rDNA sequence determination. Genomic DNA extraction, PCR-mediated amplification of the 16S rDNA, and purification of PCR products were carried out using procedures described previously (Rainey et al., 1996). Purified PCR products were sequenced using Taq DyeDeoxy Terminator Cycle Sequencing Kit (Applied Biosystems) as directed in the manufacturer's protocol. The Applied Biosystems 310 DNA Genetic Analyzer was used for the electrophoresis of the sequence reaction products.

Phylogenetic analysis. The ae 2 editor (Maidak et al., 1994) was used to align the $16 \mathrm{~S}$ rDNA sequence of strain MA140/96 ${ }^{\mathrm{T}}$ against the $16 \mathrm{~S}$ rDNA sequences of representatives of the suborder Corynebacterineae (Stackebrandt et al., 1997) available from the public databases. Pairwise evolutionary distances were computed using the correction of Jukes \& Cantor (1969). The least squares distance method of De Soete (1983) was used in the construction of the phylogenetic dendrogram from distance matrices.

Nucleotide sequence accession numbers. The strain designations and accession numbers of the reference strains used in the phylogenetic analyses are as follows: Corynebacterium glutamicum DSM 20300 ${ }^{\mathrm{T}}$, X80629; Dietzia maris DSM $43672^{\mathrm{T}}$, X79290; Gordonia aichiensis DSM 43978 ${ }^{\mathrm{T}}, \mathrm{X} 80633$; Gordonia amarae DSM 43392 ${ }^{\mathrm{T}}$, X80635; Gordonia bronchialis DSM 43247 ${ }^{\mathrm{T}}$, X79287; Gordonia hirsuta DSM $44140^{\mathrm{T}}$, X93485; Gordonia hydrophobica DSM 44015 X87340; Gordonia rubropertincta DSM 43197 ${ }^{\mathrm{T}}$, X80632; Gordonia sputi DSM $43896^{\mathrm{T}}$, X80634; Gordonia terrae DSM 43249 ${ }^{\mathrm{T}}$, X79286; Mycobacterium tuberculosis $\mathrm{H37} / \mathrm{Rv}^{\mathrm{T}}$, X55588; Nocardia asteroides DSM 43757 ${ }^{\mathrm{T}}$, X80606; Nocardia brasiliensis DSM 43758 ${ }^{\mathrm{T}}$, X80608; Nocardia transvalensis DSM 43405 , X80609; Rhodococcus equi DSM $20307^{\mathrm{T}}$, X80614; Rhodococcus erythropolis DSM $43066^{\mathrm{T}}$, X79289; Rhodococcus globerulus DSM 43954 ${ }^{\mathrm{T}}$, X80619; Rhodococcus opacus DSM 43205 ${ }^{\mathrm{T}}$, X80630; Rhodococcus rhodnii DSM 43336 ${ }^{\mathrm{T}}$, X80621; Rhodococcus rhodochrous DSM 43241 ${ }^{\mathrm{T}}$, X79288; Skermania piniformis IFO $15059^{\mathrm{T}}$, Z35435; Tsukamurella paurometabola DSM 20162 ${ }^{\mathrm{T}}$, X80628; Tsukamurella pulmonis IMMIB-D-1321 ${ }^{\mathrm{T}}$, X92981; Turicella otitidis DSM $8821^{\mathrm{T}}, \mathrm{X} 73976$.

\section{RESULTS AND DISCUSSION}

\section{Phylogenetic position of strain MA140/96}

The almost complete 16S rDNA sequence of strain MA140/96 ${ }^{\mathrm{T}}$ comprising 1465 nucleotides [ $>95 \%$ of the Escherichia coli sequence (Brosius et al., 1978)] was 


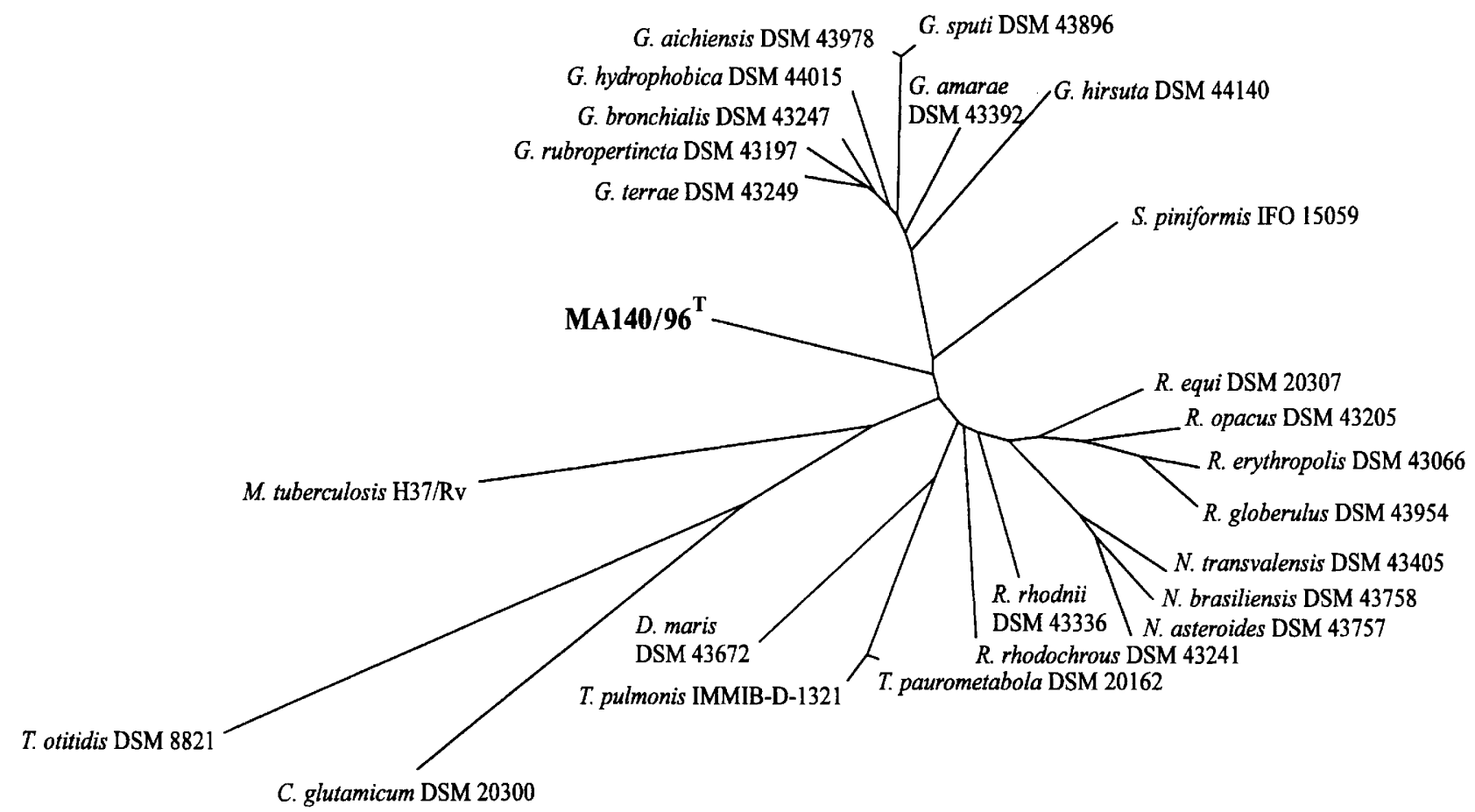

Fig. 1. Phylogenetic tree based on $16 \mathrm{~S}$ rDNA sequence comparisons demonstrating the phylogenetic position of strain MA140/96 ${ }^{\top}$. Scale bar indicates 5 nucleotide substitutions per 100 nucleotides. All strains are type strains. DSM, DSMZ Deutsche Sammlung von Mikroorganismen und Zellkulturen, Braunschweig, Germany; IFO, Institute of Fermentation, Osaka, Japan; IMMIB, Institut für Medizinische Mikrobiologie und Immunologie der Universität Bonn, Germany.

determined in this study. The phylogenetic dendrogram shown in Fig. 1 was reconstructed from evolutionary distances (Jukes \& Cantor, 1969) by the leastsquares distance method (De Soete, 1983). A total of 1386 nucleotides present in all strains between positions 38 and 1482 (E. coli positions) were used for this analysis and compared with the sequences representatives of the phylogenetically defined suborder Corynebacterineae. The 16S rDNA sequence based phylogenetic tree shown in Fig. 1 indicates the position of strain MA140/96 $6^{\mathrm{T}}$ within the radiation of representative taxa of the suborder Corynebacterineae. The 16S rDNA sequence of strain MA140/96 ${ }^{\mathrm{T}}$ contains all of the 16S rDNA signature nucleotides defined for the suborder Corynebacterineae (Stackebrandt et al., 1997). 16S rDNA sequence similarity values between the that of strain MA140/96 ${ }^{\mathrm{T}}$ and the taxa in the tree (Fig. 1) indicate that strain MA140/96 ${ }^{\mathrm{T}}$ is not closely related at the $16 \mathrm{~S}$ rDNA level to any previously described taxa. The sequence similarity values of the sequence of strain MA140/96 ${ }^{\mathrm{T}}$ to other taxa are as follows: Gordonia species $94 \cdot 2-95.6 \%$, Rhodococcus species $94 \cdot 0-95 \cdot 7 \%$, Nocardia species $94 \cdot 8-95 \cdot 7 \%, S$. piniformis $94.0 \%$, Tsukamurella species $93.9-94.1 \%$, D. maris $92.4 \%$ and $88.8-91.8 \%$ to the outgroup organisms in the tree. These values and the tree (Fig. 1) show that strain MA140/96 ${ }^{\mathrm{T}}$ is no more related and in some cases less related to any of the genera of the mycolic acid containing bacteria than those genera are to each other. Its lack of membership to one of the previously described genera based on the uniqueness of the $16 \mathrm{~S}$ rDNA sequence of strain MA140/96 ${ }^{\mathrm{T}}$ is seen when the signature nucleotides defined for the families of the suborder Corynebacterineae are searched in the sequence determined in this study. An example of this is that of the 11 signatures defined for the family Gordoniaceae (Stackebrandt et al., 1997), all but one are absent in the 16S rDNA sequence of strain MA140/96 ${ }^{\mathrm{T}}$.

The distinctness of the 16S rDNA sequence and the isolated phylogenetic position of MA140/96 ${ }^{\mathrm{T}}$ indicates that this isolate could merit genus status.

\section{Chemotaxonomy}

The hydrolysates of whole-cell cells of the strains contained the diamino acid meso-diaminopimelic acid and the sugars arabinose, galactose, mannose and ribose. This combination of the cell-wall diamino acid and sugar revealed the chemotype IV sensu Lechevalier \& Lechevalier (1970). 
Table 1. Chemotaxonomic markers of Williamsia and other genera of the suborder Corynebacterineae

Whole-cell hydrolysates of all organisms contain meso-diaminopimelic acid and arabinose + galactose. Other diagnostic sugars like madurose, i.e. 3- $O$-methyl-D-galactose (Lechevalier \& Gerber, 1970), xylose or rhamnose are lacking. Non-diagnostic sugars, i.e. glucose, mannose, ribose may be present (Lechevalier \& Lechevalier, 1970). ND, Not determined.

\begin{tabular}{|c|c|c|c|c|c|c|c|}
\hline & Acyl type* & $\begin{array}{c}\text { Major } \\
\text { menaquinone }\end{array}$ & $\mathbf{P E} \dagger$ & $\begin{array}{c}\text { Fatty acid } \\
\text { composition } \neq\end{array}$ & $\begin{array}{l}\text { Mycolate } \\
\text { size (no. } \\
\text { carbons) }\end{array}$ & $\begin{array}{c}\text { Pyrolysis } \\
\text { esters of } \\
\text { mycolates } \|\end{array}$ & $\begin{array}{c}G+C \\
\text { content } \\
(\operatorname{mol} \%)\end{array}$ \\
\hline Mycobacterium & G & MK-9(H2) & + & $\mathrm{S}, \mathrm{U}, \mathrm{T}$ & $70-90$ & $22-26$ & $70-72$ \\
\hline Tsukamurella & G & MK-9 & + & $\mathrm{S}, \mathrm{U}, \mathrm{T}$ & $64-78$ & $20: 19$ & $67-68$ \\
\hline Skermania & $\mathrm{G}$ & MK- $8(\mathrm{H} 4, \omega-\mathrm{cycl})$ & + & $\mathrm{S}, \mathrm{U}, \mathrm{T}$ & $58-64$ & $16-20$ & 68 \\
\hline Gordonia & $\mathrm{G}$ & MK-9(H2) & + & $\mathrm{S}, \mathrm{U}, \mathrm{T}$ & $54-66$ & $16-18$ & $63-69$ \\
\hline MA $140 / 96^{\mathrm{T}}$ & G & MK-9(H2) & + & S, U. T & $50-56$ & ND & $64-65$ \\
\hline Nocardia & $\mathrm{G}$ & MK- $8(\mathrm{H} 4, \omega-\mathrm{cycl})$ & + & $\mathrm{S}, \mathrm{U}, \mathrm{T}$ & $50-62$ & $12-18$ & $64-72$ \\
\hline Rhodococcus & G & $\mathrm{MK}-8(\mathrm{H} 2)$ & + & $\mathrm{S}, \mathrm{U}, \mathrm{T}$ & $34-54$ & $12-16$ & $63-73$ \\
\hline Dietzia & A & MK-8(H2) & - & $\mathrm{S}, \mathrm{U}, \mathrm{T}$ & $34-38$ & ND & 73 \\
\hline Corynebacterium & A & $\mathrm{MK}-8(\mathrm{H} 2)$ & -\# & $\mathrm{S}, \mathrm{U}^{* *}$ & $22-36$ & $8-18$ & $51-67$ \\
\hline C. amycolatum & ND & $M K-9 \dagger \dagger$ & ND & $\mathrm{S}, \mathrm{U}$ & - & - & ND \\
\hline Turicella & ND & MK-10, MK-11 & ND & $\mathrm{S}, \mathrm{U}, \mathrm{T}$ & - & - & $65-72$ \\
\hline
\end{tabular}

* G, Glycolated muramic acid; A, acetylated muramic acid.

† Phosphatidylethanolamine (Lechevalier et al., 1977, 1981); +, present; -, absent.

$¥$ S, Saturated fatty acids; U, unsaturated fatty acids; $T$, tuberculostearic acid.

$\S$ Number of carbon atoms in mycolic acid molecule, range of homologous series of mycolic acids.

\| Fatty acid methyl esters released by pyrolysis of mycolic acid methyl esters.

T 20:1, Eicosaenoic acid.

\#Present in C. bovis and C. urealyticum.

** Tuberculosterearic acid present in C. ammoniagenes, C. bovis, C. minutissimum, C. urealyticum and C. variabilis.

$\dagger \dagger$ Abbreviation MK-9 = 2-methyl-3-nonaisoprenyl-1, 4-naphthoquinone (Collins \& Jones, 1981; Kroppenstedt, 1985; Goodfellow, 1989).

The following phospholipids were detected: phosphatidylethanolamine, phosphatidylinositol, phosphatidylglycerol, and diphosphatidylglycerol. According to the phospholipid classification of Lechevalier et al. (1977) the strains showed phospholipid type II [containing phosphatidylethanolamine but lacking phosphatidylcholine and glucosamine-containing phospholipid (Glu-Nu)]. The only menaquinone found was $\mathrm{MK}-9\left(\mathrm{H}_{2}\right)$.

The fatty acid pattern was mainly composed of palmitic acid (23.6\%), palmitoleic acid $(16.5 \%)$ and another hexadecenoic acid 16:1cis $11(1.4 \%)$, oleic acid $(29.9 \%)$, stearic acid $(2.9 \%)$ and the 10-methylbranched tuberculostearic acid $(23 \cdot 1 \%)$. Small amounts of $17: 0(1.4 \%)$ and $17: 1(1.3 \%)$ could be found in addition. iso- and anteiso-branched and cyclopropane fatty acids were absent. This fatty acid pattern corresponds to fatty acid type $1 \mathrm{~b}$ of Kroppenstedt (1985). The gas-chromatographic analyses of the mycolic acid revealed a carbon-chain length of $\mathrm{C}_{50}-\mathrm{C}_{56}$ and a quantitative distribution of $\mathrm{C}_{50}$ $10 \%, \mathrm{C}_{51} 3 \%, \mathrm{C}_{52} 34 \%, \mathrm{C}_{53} 5 \%, \mathrm{C}_{54} 36 \%, \mathrm{C}_{55} 6 \%$ and $\mathrm{C}_{56} 6 \%$. On a thin-layer plate a single spot was detected showing an $R_{f}$-value of 0.35 which resembles mycolic acids which are synthesized by Rhodococcus, Nocardia and Gordonia (Minnikin et al., 1975).

A detailed comparison of chemotaxonomic data of MA140/96 ${ }^{\mathrm{T}}$ with other mycolic acid-containing genera is given in Table 1. Although almost all chemotaxonomic markers of MA140/96 ${ }^{\mathrm{T}}$ resemble those of Gordonia, members of these two genera can easily be differentiated by the chain length of their mycolic acids. MA140 $/ 96^{\mathrm{T}}$ synthesized a homologous series of mycolic acids of a chain length of 50-56 carbon atoms whereas those of Gordonia spp. are longer. Based on the mycolic acids it seems that MA140/96 $6^{\mathrm{T}}$ takes an intermediate position between Rhodococcus (mycolic acid chain length of 34-54) and Gordonia (mycolic acid chain length of 54-66). Also, MA140/96 ${ }^{\mathrm{T}}$ contained more tuberculostearic acid $(>20 \%)$ than any of the Gordonia species described so far.

\section{Morphological characteristics}

Strain MA140/96 ${ }^{\mathrm{T}}$ grew as round, slightly convex, colonies that were $1-3 \mathrm{~mm}$ in diameter and were mainly pale yellow to intense yellow. The cells were Gram-positive, non-acid-fast, non-motile, thin irreg- 


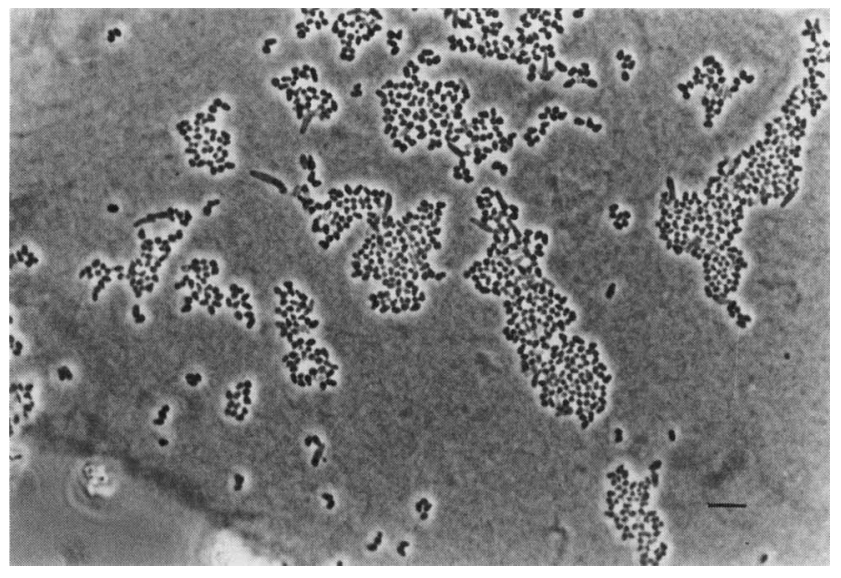

Fig. 2. Phase-contrast photomicrograph of strain MA140/96 ${ }^{\top}$ grown on tuberculostearic acid agar for $48 \mathrm{~h}$ (bar, $5 \mu \mathrm{m}$ ).

ular rods or coccoid $(0.5-0.8 \mu \mathrm{m} \times 1.0-2.0 \mu \mathrm{m})$ that occurred singly, or in small clusters (Fig. 2). Some longer cells $(5 \mu \mathrm{m})$ were also observed (Fig. 2), but like many other members of the suborder Corynebacterineae the cell morphology was amycelial. Endospores were not observed. Transmission electron micrographs (Fig. 3a) revealed the presence of hairy structures distributed over the whole surface of each cell. With the exception of the genus Bogoriella (Groth et al., 1997) and the species Rhodococcus percolatus (Briglia et al., 1996), such structures have not been found previously in coryneform organisms. However, the appendages of the strain MA140/96 ${ }^{\mathrm{T}}$ were not visible in negative-stained preparations (Fig. 3b), which indicates that they may be fibrillar capsular material rather than true fimbriae.

\section{Cultural characteristics}

Strain MA140/96 ${ }^{\mathrm{T}}$ was isolated on tryptone soy agar (Difco) at $22^{\circ} \mathrm{C}$, but also grow on Bacto nutrient agar in a temperature range from 10 to $37^{\circ} \mathrm{C}$. Growth at low and high temperatures was delayed and reduced, especially at $37^{\circ} \mathrm{C}$. At $45^{\circ} \mathrm{C}$ only traces of growth were observed.

\section{Physiological characteristics}

The physiological properties of strain MA140/96 $\mathrm{T}$ can be summarized as follows: Utilization of the following carbon sources was observed after $4 \mathrm{~d}$ incubation at $30{ }^{\circ} \mathrm{C}$ : acetate, adonitol, citrate, $\mathrm{D}$-fructose, fumarate, D-gluconate, D-mannitol, D-mannose, propionate, putrescine, L-rhamnose, sorbitol, sucrose and pyruvate. After prolonged incubation $(10 \mathrm{~d})$ growth with Dglucose, DL-3-hydroxybutyrate, L-alanine and Lproline was observed in addition. The following carbon sources could not be used for growth: $\mathrm{N}$ acetyl-D-galactosamine, $N$-acetyl-D-glucosamine, cis-
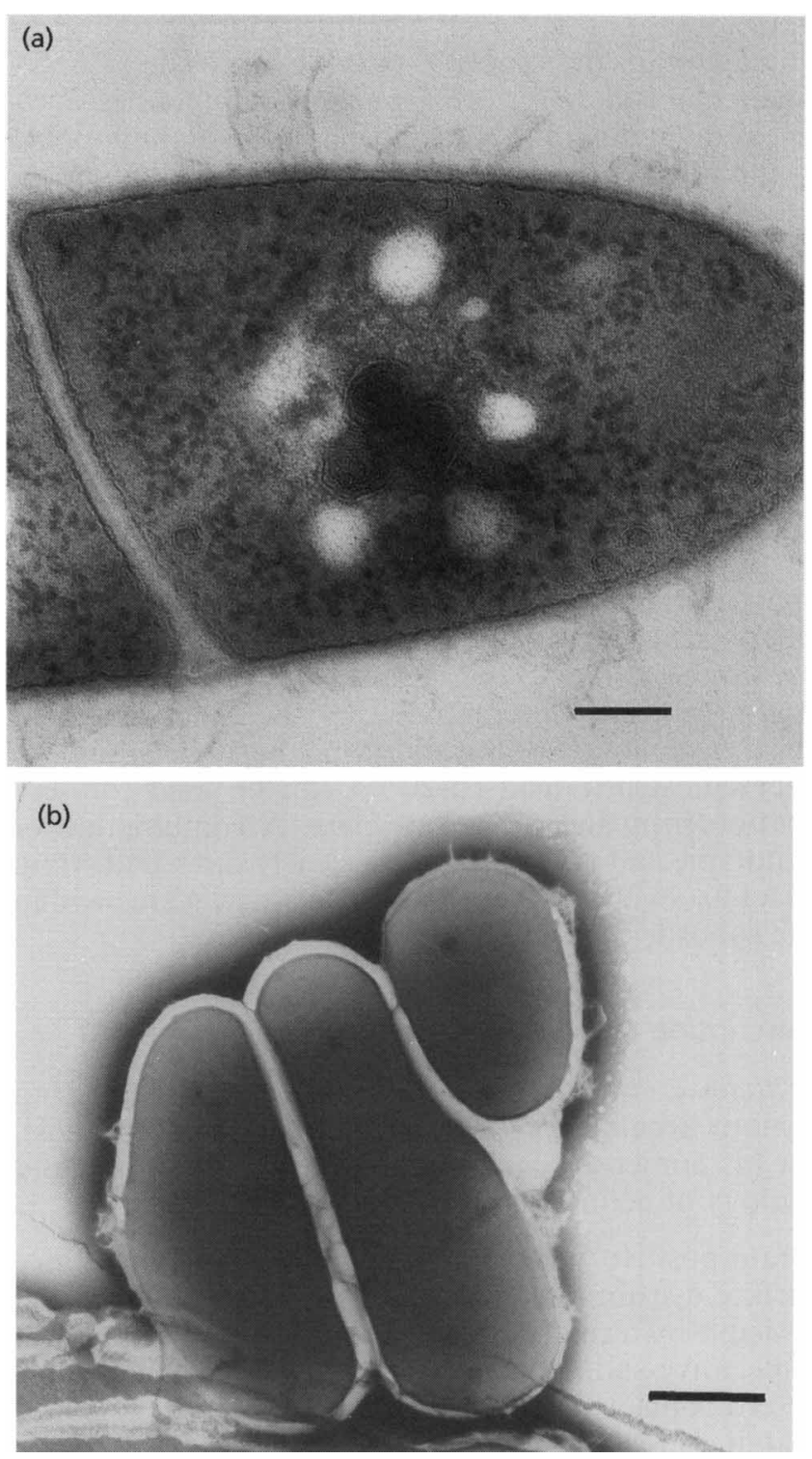

Fig. 3. Electron micrographs of strain $M A 140 / 96^{\top}$. (a) Thin section transmission micrograph; bar, $100 \mathrm{~nm}$. (b) Negatively stained preparation; bar, $500 \mathrm{~nm}$. The fimbrial-looking structures visible in thin sections (a) were not detected in negatively stained preparations (b), indicating that they are of capsular type rather than fimbrial in nature.

aconitate, trans-aconitate, $\beta$-alanine, 4-aminobutyrate, $\mathrm{L}$-arabinose, $p$-arbutin, L-aspartate, azelate, D-cellobiose, glutarate, L-histidine, 3-hydroxybenzoate, 4-hydroxybenzoate, inositol, itaconate, DLlactate, L-leucine, L-malate, D-maltitol, D-maltose, $\alpha$ D-melibiose, mesaconate, 2-oxoglutarate, L-ornithine, phenylacetate, L-phenylalanine, salicin, L-serine, suberate, D-trehalose, L-tryptophan or D-xylose. The following chromogenic substrates were hydrolysed after $4 \mathrm{~d}$ incubation ( $\mathrm{pNP}=$ para-nitrophenyl; $\mathrm{pNA}$ $=$ para-nitroanilide $): \mathrm{pNP}-\alpha-\mathrm{D}$-glucopyranoside, bispNP-phosphate. No hydrolysis of aesculin, $p N P-\beta$-D- 
galactopyranoside, $\mathrm{pNP}-\beta$-D-glucuronide, $\mathrm{pNP}-\beta$-Dglucopyranoside, $\mathrm{pNP}-\beta$-D-xylopyranoside, $\mathrm{pNP}$ phenylphosphate, pNP-phosphoryl-choline, 2deoxythymidine- 5 '-pNP phosphate, L-alanine-pNA, L-glutamate- $\gamma$-(3-carboxy)-pNA and L-proline-pNA. No acid formation (in Hugh-Leifson medium) from the following carbohydrates was observed: Larabinose, D-cellobiose, D-glucose, lactose, D-maltose, D-mannose, $\alpha$-D-melibiose, methyl $\alpha$-D-glucopyranoside, $\alpha$-D-raffinose, L-rhamnose, sucrose, salicin, D-trehalose, D-xylose, D-arabitol, adonitol, dulcitol, meso-erythritol, meso-inositol, D-mannitol or D-sorbitol.

16S rDNA analysis clearly indicated that this organism is not a member of the genus Gordonia, because the signature nucleotides of the family Gordoniaceae are not present. Although the chemotaxonomic properties are similar to that of the species of the genus Gordonia, it can be easily differentiated by the chain length of their mycolic acids. In addition, the high amout of tuberculostearic acid $(>20 \%)$ can be used for separation from the genus Gordonia. A combination of genotypic and phenotypic data clearly show that strain MA140/96 $6^{\mathrm{T}}$ merits recognition as a new genus within the suborder Corynebacterineae.

Williamsia (Wil.li.ams.ia. M.L. fem. n. named to honour Stanley T. Williams, a British microbiologist, for his numerous contributions to the taxonomy and ecology of actinomycetes).

Gram-positive, non-spore forming short rods. A hairy surface distributed over the whole surface of each cell is visible by transmission electron microscopy, but not in negative-stained preparations. Aerobic and chemoheterotrophic. The diagnostic amino acid is mesodiaminopimelic acid and the major cell-wall sugars are arabinose, galactose, mannose and ribose (wall chemotype IV sensu Lechevalier \& Lechevalier, 1970). Shortchain mycolic acids are present (carbon-chain length of $\mathrm{C}_{50}-\mathrm{C}_{56}$ ). The fatty acid pattern is mainly composed of straight-chain saturated and monounsaturated fatty acids. Tuberculostearic acid is present in large amounts ( $>20 \%$ of the whole-cell fatty acid). The major polar lipids are phosphatidylethanolamine, phosphatidylinositol, phosphatidylglycerol and diphosphatidylglycerol. Menaquinone MK- $9\left(\mathrm{H}_{2}\right)$ is the only isoprenologue. On the basis of $16 \mathrm{~S}$ DNA sequence analysis it is a member of the suborder Corynebacterinae. The $\mathrm{G}+\mathrm{C}$ content of the DNA is 64$65 \mathrm{~mol} \%$.

\section{Description of Williamsia muralis sp. nov.}

Williamsia muralis [mu.ra'lis. L. adj. muralis, -le pertaining or belonging to wall(s)].

Coccoid cells without branching $(0.4-0.5 \mu \mathrm{m}$ in width, $0.6-1.4 \mu \mathrm{m}$ in length). Smooth, saffron yellow colour on TSB agar (BBL). The temperature range for growth is 10 to $37^{\circ} \mathrm{C}$, optimum at $30^{\circ} \mathrm{C}$. No growth could be detected at 4 or $41^{\circ} \mathrm{C}$. Good growth was observed on nutrient agar (Difco), R2A agar (Difco) and TSB agar (BBL). Acetate, adonitol, citrate, $D$-fructose, fumarate, D-gluconate, D-mannitol, D-mannose, propionate, putrescine, L-rhamnose, sorbitol, sucrose and pyruvate are utilized (after $4 \mathrm{~d}$ incubtion at $30^{\circ} \mathrm{C}$ ) as sole source of carbon. In addition, D-glucose, DL-3-hydroxybutyrate, L-alanine and L-proline are utilized after $10 \mathrm{~d}$ incubation. $\mathrm{pNP}-\alpha$-D-glucopyranoside and bis-pNPphosphate are hydrolysed. The $\mathrm{G}+\mathrm{C}$ content of the DNA is $64.8 \mathrm{~mol} \%$. Isolated from indoor building material of a children's day care centre, Finland. MA140/96 ${ }^{\mathrm{T}}$ is the type strain of the species and has been deposited at the German Collection of Microorganisms and Cell Cultures as strain DSMZ $44343^{\mathrm{T}}$.

\section{ACKNOWLEDGEMENTS}

We thank Gabriele Pötter-Reinemann, F. Frerichs and Verena Schmidt for technical assistance. M.S.-S. thanks the Academy of Finland and Helsinki University Fund for Centers of Excellence for financial support (grant no. 34519). Irina Tsitko and Raimo Mikkola are thanked for analytical help. Helsinki University EM-unit (Biocenter) is thanked for the use of their equipment.

\section{REFERENCES}

Andersson, M., Laukkanen, M., Nurmiaho-Lassila, E.-L., Rainey, F., Niemelä, S. \& Salkinoja-Salonen, M. (1995). Bacillus thermosphaericus sp. nov. a new thermophilic ureolytic Bacillus isolated from air. Syst Appl Microbiol 18, 203-220.

Andersson, M. A., Nikulin, M., Köljalg, U., Andersson, M. C., Rainey, F., Reijula, K., Hintikka, E.-L. \& Salkinoja-Salonen, M. (1997). Bacteria, molds, and toxins in water-damaged building materials. Appl Environ Microbiol 63, 387-393.

Briglia, M., Rainey, F. A., Stackebrandt, E., Schraa, G. \& SalkinojaSalonen, M. (1996). Rhodococcus percolatus sp. nov., a bacterium degrading 2,4,6 tetrachlorophenol. Int $J$ Syst Bacteriol 46,

Brosius, J., Palmer, M. L., Kennedy, P. J. \& Noller, H. F. (1978). Complete nucleotide sequence of the $16 \mathrm{~S}$ ribosomal RNA gene from Escherichia coli. Proc Natl Acad Sci USA 75, 4801-4805.

Collins, M. D. \& Jones, D. (1981). Distribution of isoprenoid quinone structural types in bacteria and their taxonomic implications. Microbiol Rev 45, 316-354.

De Soete, G. (1983). A least squares algorithm for fitting additive trees to proximity data. Psychometrika 48, 621-626.

DSMZ (1998). Catalogue of Strains, 5th edn. German Collection of Microorganisms and Cell Cultures, Braunschweig, Germany: Deutsche Sammlung von Mikroorganismen und Zellkulturen.

Gerhardt, P., Murray, R. G. E., Wood, W. A. \& Krieg, N. R. (1994). Methods for General and Molecular Bacteriology. Washington, DC: American Society for Microbiology.

Goodfellow, M. (1989). The actinomycetes. I. Suprageneric classification of actinomycetes. In Bergey's Manual of Systematic Bacteriology, vol. 4, pp. 2333-2339. Edited by S. T. Williams, M. E. Sharpe \& J. G. Holt. Baltimore: Williams \& Wilkins. 
Groth, I., Schumann, P., Rainey, F. A., Martin, K., Schuetze, B. \& Augsten, K. (1997). Bogoriella caseolytica gen. nov. sp. nov., a new alkaliphilic actinomycete from a soda lake in Africa. Int $J$ Syst Bacteriol 47, 788-794.

Jukes, T. H. \& Cantor, C. R. (1969). Evolution of protein molecules. In Mammalian Protein Metabolism, vol. 3, pp. 21-132. Edited by H. N. Munro. New York: Academic Press.

Kämpfer, P., Denner, E. B. M., Meyer, S., Moore, E. R. B. \& Busse, H.-J. (1997). Classification of "Pseudomonas azotocolligans" Anderson 1955, 132, in the genus Sphingomonas as Sphingomonas trueperi sp. nov. Int $J$ Syst Bacteriol 47, 577-583.

Klatte, S. (1994). Polyphasische automatisierte Identifizierung der Gattungen Corynebacterium Lehmann \& Neumann 1896 und Rhodococcus Zopf 1891. PhD thesis, University of Osnabrück.

Kroppenstedt, R. M. (1985). Fatty acid and menaquinone analysis of actinomycetes and related organisms. In Chemical Methods in Bacterial Systematics, pp. 173-199. Edited by M. Goodfellow \& D. E. Minnikin. London \& New York: Academic Press.

Kroppenstedt, R. M., Korn-Wendisch, F., Fowler, V. J. \& Stackebrandt, E. (1981). Biochemical and molecular genetic evidence for a transfer of of Actinoplanes armeniacus into the family Streptomycetaceae. Zentbl Bakteriol Hyg I Abt Orig C2, 254-262.

Lechevalier, M. P. \& Gerber, N. N. (1970). The identity of 3-Omethyl-D-galactose with madurose. Carbohydr Res 13, 451-454.

Lechevalier, H. A. \& Lechevalier, M. P. (1970). A critical evaluation of the genera of aerobic actinomycetes. In The Actinomycetales, pp. 393-405. Edited by H. Prauser. Jena: Gustav Fischer Verlag.

Lechevalier, M. P., de Biévre, C. \& Lechevalier, H. A. (1977). Chemotaxonomy of aerobic actinomycetes: Phospholipid composition. Biochem Ecol Syst 5, 249-260.

Lechevalier, M. P., Stern, A. E. \& Lechevalier, H. A. (1981). Phospholipids in the taxonomy of actinomycetes. Zentbl Bakteriol Parasitenkd Infektionskr Hyg I Abt Suppl 11, 111-116.
Maidak, B. L., Larsen, N., McCaughey, M. J., Overbeek, R., Olsen, G. J., Fogel, K., Blandy, J. \& Woese, C. R. (1994). The Ribosomal Database Project. Nucleic Acids Res 22, 3485-3487.

Maroni, M., Seifert, B. \& Lindvall, T. (editors) (1995). In Air Quality Monographs, vol. 3, pp. 149-160. Amsterdam: Elsevier.

Miller, L. \& Berger, T. (1984). Bacterial identification by gas chromatography and whole cell fatty acids. Gas Chromatography Application Note 228-41. Hewlett Packard.

Minnikin, D. E., Alshamaony, L. \& Goodfellow, M. (1975). Differentiation of Mycobacterium, Nocardia and related taxa by thin-layer chromatographic analysis of whole-organism methanolysates. J Gen Microbiol 88, 200-204.

Minnikin, D. E., O'Donnell, A. G., Goodfellow, M., Alderson, G., Athalye, M. \& Parlett, J. H. (1984). An integrated procedure for extraction of bacterial isoprenoid quinones and polar lipids. $J$ Microbiol Methods 2, 233-241.

Nohynek, L. J., Suhonen, E. L., Nurmiaho-Lassila, E.-L., Hantula, J. \& Salkinoja-Salonen, M. (1995). Description of four pentachlorophenol-degrading bacterial strains as Sphingomonas chlorophenolica sp. nov. Syst Appl Microbiol 18, 527-538.

Rainey, F. A., Ward-Rainey, N., Kroppenstedt, R. M. \& Stackebrandt, E. (1996). The genus Nocardiopsis represents a phylogenetically coherent taxon and a distinct actinomycete lineage: proposal of Nocardiopsaceae fam. nov. Int $J$ Syst Bacteriol 46, 1088-1092.

Sasser, M. (1990). Identification of bacteria by gas chromatography of cellular fatty acids. USFCC Newsl 20, 1-6.

Stackebrandt, E., Rainey, F. A. \& Ward-Rainey, N. L. (1997). Proposal for a new hierarchic classification system, Actinobacteria classis nov. Int J Syst Bacteriol 47, 479-491.

Staneck, J. L. \& Roberts, G. D. (1974). Simplified approach to identification of aerobic actinomycetes by thin layer chromatography. Appl Microbiol 28, 226-231.

Uchida, K. \& Aida, K. (1977). Acyl type of bacterial cell wall: its simple identification by colorimetric method. $J$ Gen Appl Microbiol 23, 249-260. 